\title{
STUDI POLA PENGGUNAAN ANTIBIOTIK DAN ANALGESIK PADA PASIEN INFEKSI SALURAN KEMIH (ISK) (Studi Dilaksanakan di Instalasi Rawat Inap RSUD Abdul Wahab Sjahranie)
}

\author{
Sintya Yustira Verananda ${ }^{1, *}$, Sabaniah Indjar Gama ${ }^{1}$, Jaka Fadraersada $^{1,2}$ \\ ${ }^{1}$ Laboratorium Penelitian dan Pengembangan Kefarmasian "Farmaka Tropis", \\ Fakultas Farmasi, Universitas Mulawarman, Samarinda, Indonesia \\ ${ }^{2}$ Kelompok Bidang Ilmu Farmasi Klinik dan Komunitas, Fakultas Farmasi, \\ Universitas Mulawarman, Samarinda, Indonesia \\ *Email: syverananda@yahoo.co.id
}

\begin{abstract}
Urinary tract infection(UTI) is the second most common illness experienced by inpatients in the hospital and require antibiotics as the main treatment. Twenty ti sixty percent of antibiotic use in hospitals is considered not appropriate so as to cause resistance. This research aims to know the patternof treatment, UTI sufferers characteristics and interactions between antibiotics with analgesics. This research was done in a retrospective and descriptive are elaborated by taking the patient's medical record data. The results of this study indicate that the characteristics of patients the laergest patients whom diagnosed with UTI's are $81 \%$ women, teens and elderly employment 21\%, a housewife (IRT) $32 \%$, and without the use of a catheter is $86 \%$. The antibiotics and analgesics are the most widely used is the cephalosporin $67 \%$ i.e. ceftriaxon $30 \%$ and $96 \%$ non opioid analgesic i.e. $71 \%$ of paracetamol. And there is no interaction between antibiotics and analgesics are used.
\end{abstract}

Keyword: Interaction, Paracetamol, Ceftriaxone.

\begin{abstract}
ABSTRAK
Infeksi saluran kemih (ISK) merupakan penyakit kedua yang paling banyak dialami oleh pasien rawat inap di Rumah Sakit dan memerlukan antibiotik sebagai pengobatan utama. Sebesar 20-65\% penggunaan antibiotik di rumah sakit dianggap tidak tepat sehingga dapat menimbulkan resistensi. Penelitian ini bertujuan untuk mengetahui pola pengobatan, karakteristik penderita ISK dan interaksi antara antibiotik dengan analgesik. Penelitian ini dilakukan secara retrospektif dan dijabarkan secara deskriptif dengan mengambil data rekam medis pasien ISK. Hasil penelitian ini menunjukkan bahwa karakteristik pasien yang terserang ISK terbesar merupakan perempuan $81 \%$, usia remaja dan lansia $21 \%$, pekerjaan ibu rumah tangga (IRT) 32\%, dan tanpa penggunaan kateter $86 \%$. Golongan antibiotik dan analgesik yang paling banyak digunakan adalah golongan sefalosporin $67 \%$ yaitu seftriakson 30\% dan analgesik non opioid $96 \%$ yaitu parasetamol $71 \%$. Dan tidak ada interaksi antara antibiotik dan analgesik yang digunakan.
\end{abstract}

Kata Kunci: Interaksi, Parasetamol, Seftriakson.

DOI: https://doi.org/10.25026/mpc.v6i1.280 


\section{PENDAHULUAN}

Infeksi saluran kemih (ISK) adalah keadaan klinis adanya mikroorganisme dalam urin dan berpotensi untuk masuk ke dalam saluran kemih bagian atas, menginvasi mukosa pelvis ginjal, dan meluas ke dalam jaringan interstisial ginjal [1]. Infeksi saluran kemih merupakan penyakit infeksi kedua yang paling banyak dialami pasien rawat inap di rumah sakit, sekitar 150 juta penduduk di seluruh dunia tiap tahunnya terdiagnosis menderita infeksi saluran kemih. Menurut WHO angka kejadian ISK di dunia 8,3 juta kasus/ tahun, sedangkan menurut DEPKES tahun 2014 di Indonesia terjadi 180.000 kasus baru/ tahun. Data penelitian epidemiologi klinik melaporkan $25-35 \%$ perempuan dewasa pernah mengalami infeksi saluran kemih (ISK), umumnya empat sampai lima kali lebih mudah terinfeksi ISK dibandingkan pria [2].

E. coli merupakan pathogen paling umum menyebabkan ISK, lebih dari $80 \%$ dapat menyebabkan komplikasi ISK, terdapat pula beberapa pathogen lain yang menyebabkan ISK biasanya disebut patogen sekunder seperti Klebsiella spp, Enterobacter, Proteus spp [3]. Pasien dapat didiagnosis infeksi saluran kemih apabila urinnya mengandung lebih dari $10^{5}$ bakteri/mL, sedangkan dalam keadaan normal urin juga mengandung mikroorganisme sekitar $10^{2}$ sampai $10^{4}$ bakteri/mL urin.

Tujuan terapi penyakit ISK adalah untuk mencegah atau mengobati meluasnya infeksi (systemic infection), eradikasi mikroorganisme penginfeksi, dan mencegah kekambuhan, sehingga dibutuhkan tata laksana terapi ISK yang tepat dan rasional. Antibiotik merupakan golongan obat yang paling banyak digunakan dalam pengobatan infeksi saluran kemih, di negara berkembang 30$80 \%$ penderita yang dirawat di rumah sakit mendapat antibiotik. Berdasarkan persentase tersebut, 20-65\% penggunaannya dianggap tidak tepat.
Penulisan resep dan penggunaan antibiotik yang tidak tepat tersebut cenderung meluas. The Center for Disease Control and Prevention in USA menyebutkan terdapat 50 juta peresepan antibiotik yang tidak diperlukan (unnecessary prescribing) dari 150 juta peresepan setiap tahun [1].

Antibiotik merupakan golongan obat yang paling banyak digunakan di dunia terkait dengan banyaknya kejadian infeksi bakteri. Penggunaan antibiotik secara tidak tepat dapat menimbulkan terjadinya peningkatan efek samping dan toksisitas antibiotika, pemborosan biaya dan tidak tercapainya manfaat klinik yang optimal dalam pencegahan maupun pengobatan penyakit infeksi. Hal tersebut yang menjadi pertimbangan peneliti tertarik untuk melakukan penelitian mengenai studi pola penggunaan antibiotik dan analgesik pada pasien (ISK) di instalasi rawat inap RSUD Abdul Wahab Sjahranie.

\section{METODE}

Penelitian ini dilakukan pada bulan Juli hingga September tahun 2017, di instalasi rawat inap RSUD Abdul Wahab Sjahranie Samarinda. Penelitian ini menggunakan metode penelitian secara retrospektif yang dianalisis secara deskriptif. Teknik pengambilan sampel yang dilakukan adalah teknik total sampling yang akan diseleksi kembali berdasarkan kriteria inklusi dan eksklusi. Data yang diambil adalah data pasien yang mengalami infeksi saluran kemih selama tahun 2016 dan medapatkan terapi antibiotik dan analgesik.

\section{HASIL DAN PEMBAHASAN}

\section{Jenis Kelamin}

Penelitian mengenai data karakteristik jenis kelamin penderita infeksi saluran kemih dilakukan pada 57 pasien yang dirawat inap di RSUD Abdul Wahab Sjahranie Samarinda pada tahun 2016. Hasil karakteristik jenis kelamin 
dapat dilihat pada tabel 1. Berdasarkan tabel tersebut diketahui terdapat $46(81 \%)$ pasien berjenis kelamin perempuan dan $11(19 \%)$ pasien berjenis kelamin lakilaki. Pada penelitian ini penderita ISK yang berjenis kelamin perempuan lebih banyak dibandingkan dengan penderita berjenis kelamin laki-laki, hal ini disebabkan karena wanita memiliki uretra yang lebih pendek dibanding laki-laki sehingga mikroorganisme penginfeksi lebih mudah masuk dan menginfeksi saluran kemih [4].

\section{Usia}

Penelitian mengenai data karakteristik usia penderita infeksi saluran kemih dibagi dalam 6 kelompok usia, yaitu balita 0-5 tahun, anak-anak 5-
11 tahun, remaja 12-25 tahun, dewasa 2645 tahun, lansia 46-65 tahun, dan manula 65 tahun keatas. Hasil karakteristik usia dapat dilihat pada tabel 2. Hasil penelitian menunjukkan bahwa penderita ISK paling banyak terjadi pada usia remaja $12(21 \%)$ dan manula $12(21 \%)$, pada usia remaja hal ini dapat terjadi karena adanya infeksi menular melalui hubungan seksual dan kurangnya menjaga kebersihan saluran kemih [1]. Pada pasien manula terjadi karena penurunan fungsi saluran kemih dan produksi hormon estrogen yang menurun yang menyebabkan meningkatnya $\mathrm{pH}$ pada cairan vagina sehingga terjadi meningkatkan risiko perkembangan mikrorganisme [4].

Tabel.1 Karaktertistik Jenis Kelamin Pasien Infeksi Saluran Kemih diinstalasi Rawat Inap RSUD Abdul Wahab Sjahranie Samarinda

\begin{tabular}{ccc}
\hline Jenis kelamin & Jumlah & Presentase jumlah (\%) \\
\hline Perempuan & 46 & 81 \\
Laki-laki & 11 & 19 \\
\hline Total & 57 & 100 \\
\hline
\end{tabular}

Tabel 2. Karaktertistik Usia Pasien Infeksi Saluran Kemih diinstalasi Rawat Inap RSUD Abdul Wahab Sjahranie Samarinda

\begin{tabular}{|c|c|c|c|}
\hline Penggolongan & Rentang usia (tahun) & Jumlah & Presentase jumlah (\%) \\
\hline Balita & $0-5$ & 11 & 19 \\
\hline Anak-anak & $5-11$ & 6 & 11 \\
\hline Remaja & $12-25$ & 12 & 21 \\
\hline Dewasa & $26-45$ & 9 & 16 \\
\hline Lansia & $46-65$ & 7 & 12 \\
\hline Manula & 65- atas & 12 & 21 \\
\hline \multicolumn{2}{|c|}{ Total } & 57 & 100 \\
\hline
\end{tabular}

Tabel 3. Karaktertistik Pekerjaan Infeksi Saluran Kemih diinstalasi Rawat Inap RSUD Abdul Wahab Sjahranie Samarinda

\begin{tabular}{ccc}
\hline Pekerjaan & Jumlah & Presentase jumlah (\%) \\
\hline IRT & 20 & 35 \\
Anak & 15 & 26 \\
Pelajar & 10 & 17 \\
Pegawai swasta & 8 & 14 \\
PNS & 2 & 4 \\
Dokter & 1 & 2 \\
Petani & 1 & 2 \\
\hline Total & 57 & 100 \\
\hline
\end{tabular}


Tabel 4. Karaktertistik Penggunaan Kateter Infeksi Saluran Kemih diinstalasi Rawat Inap RSUD Abdul Wahab Sjahranie Samarinda

\begin{tabular}{ccc}
\hline Kateter & Jumlah $(\boldsymbol{\%})$ & Presentase jumlah $(\boldsymbol{\%})$ \\
\hline Menggunakan kateter & 8 & 14 \\
Tidak menggunakan kateter & 49 & 86 \\
\hline Total & 57 & 100 \\
\hline
\end{tabular}

Tabel 5. Karaktertistik Penggunaan Analgesik pada Infeksi Saluran Kemih diinstalasi Rawat Inap RSUD Abdul Wahab Sjahranie Samarinda

\begin{tabular}{cccccc}
\hline No & Golongan obat & Jenis obat & Jumlah obat & $\begin{array}{c}\text { Presentase jenis } \\
\text { obat }(\boldsymbol{\%})\end{array}$ & $\begin{array}{c}\text { Presentase golongan } \\
\text { obat (\%) }\end{array}$ \\
\hline 1 & Non-opioid & Parasetamol & 54 & 71 & 96 \\
& & Metamizol & 8 & 10 & \\
& & Ketoprofen & 5 & 7 & \\
& & Ibuprofen & 3 & 4 & 4 \\
\multirow{4}{*}{2} & Ketorolak & 3 & 4 & 100 \\
\hline & Opioid & Tramadol & 2 & 3 & \\
& & kodein & 1 & 1 & \\
\hline
\end{tabular}

Tabel 6. Karakteristik Penggunaan Antibiotik pada Infeksi Saluran Kemih diinstalasi Rawat Inap RSUD Abdul Wahab Sjahranie Samarinda

\begin{tabular}{|c|c|c|c|c|c|}
\hline No & Golongan obat & Jenis obat & Jumlah obat & $\begin{array}{c}\text { Presentase jenis } \\
\text { obat }(\%)\end{array}$ & $\begin{array}{c}\text { Presentase golongan } \\
\text { obat }(\%)\end{array}$ \\
\hline \multirow[t]{6}{*}{1} & Sefalosporin & Seftriakson & 28 & 30 & 67 \\
\hline & & Sefiksim & 15 & 16 & \\
\hline & & Sefotaksim & 14 & 15 & \\
\hline & & Sefobaktam & 4 & 4 & \\
\hline & & Seftazidin & 1 & 1 & \\
\hline & & Sefadroksil & 1 & 1 & \\
\hline \multirow[t]{2}{*}{2} & Kuinolon & Siprofloksasin & 14 & 15 & 16 \\
\hline & & Levofloksasin & 1 & 1 & \\
\hline 3 & Penisillin & Ampisillin & 5 & 6 & 6 \\
\hline 4 & Aminoglikosida & Gentamisin & 4 & 4 & 4 \\
\hline 5 & Karbapenem & Meropenem & 3 & 3 & 3 \\
\hline 6 & Metronidazol & Metronidazol & 3 & 3 & 3 \\
\hline 7. & Sulfonamida & Kotrimoksazol & 1 & 1 & 1 \\
\hline \multicolumn{3}{|c|}{ Total } & 94 & 100 & 100 \\
\hline
\end{tabular}

\section{Pekerjaan}

Penelitian mengenai data karakteristik pekerjaan penderita infeksi saluran kemih dapat dilihat pada tabel 3. Berdasarkan data penelitian faktor risiko terbesar ISK adalah IRT (35\%) dan anak $(26 \%)$ hal ini disebabkan oleh pada anakanak kurangnya menjaga kebersihan organ intim, dan pada IRT karena hubungan seksual, dan penggunaan kontrasepsi yang dapat menyebabkan menurunkan flora normal dan kolonisasi bakteri yang meningkatkan risiko terjadinya ISK [2].

\section{Penggunaan Kateter}

Penelitian mengenai data karakteristik penggunaan kateter 
penderita infeksi saluran kemih dapat dilihat pada tabel 4, berdasarkan hasil penelitian diperoleh data penderita yang tidak menggunakan kateter 49 (86\%) lebih banyak dibandingkan dengan penderita yang menggunakan kateter 8 (14\%). Hal ini menunjukkan bahwa tidak adanya penggaruh penggunaan kateter sebagai faktor risiko terjadinya ISK, namun penggunaan kateter dirumah sakit dapat menjadi faktor risiko penyebab ISK, apabila penggunaan kateter dalam jangka panjang dan pemasangan yang tidak aseptis dapat menyebabkan menurunkan daya tahan alami dari traktus urinarius inferior dan mengiritasi mukosa saluran kemih sehingga menimbulkan jalur artifisial yang memudahkan mikroorganisme untuk masuk kedalam sistem perkemihan yang menyebabkan terjadinya infeksi [5].

\section{Pola Penggobatan}

\section{Analgesik}

Data penelitian mengenai pola penggunaan analgesik dapat dilihat pada tabel 5. Berdasarkan data penelitian analgesik yang paling banyak digunakan adalah golongan non opioid yaitu parasetamol $(71 \%)$ dan metamizole (10\%). Penggunaan parasetamol sebagai analgesik bersamaan dengan antibiotik secara sinergis terbukti efektif dalam penyembuhan infreksi saluran kemih, terutama dalam meredakan gejala berupa nyeri [6]. Parasetamol memiliki waktu paruh 30 menit, dengan waktu paruh plasma 1-3 jam, diekskresikan melalui ginjal sebagaian kecil sebagai parasetamol dan sebagian besar dalam bentuk konjugasi. Parasetamol memiliki efek analgesik yang serupa dengan salisilat yaitu menghilangkan nyeri ringan hingga sedang dengan cara menghambat enzim siklooksigenase sehingga konversi asam arakidonat menjadi $\mathrm{PGG}_{2}$ terganggu. [7]

\section{Antibiotik}

Data penelitian mengenai pola penggunaan antibiotik dapat dilihat pada tabel 6. Berdasarkan data penelitian antibiotik yang paling banyak digunakan adalah golongan sefalosporin $(67 \%)$ dan kuinolon (16\%). Pada golongan sefalosporin yang paling banyak seftriakson (30\%) dan golongan kuinolon yang paling banyak yaitu siprofloksasin $(15 \%)$

Seftriakson merupakan antibiotik golongan sefalosporin generasi ketiga merupakan antibiotik berspektrum luas yang efek kerjanya dapat mencapai sistem saraf pusat. Obat golongan ini dapat melakuan penetrasi ke dalam jaringan, cairan tubuh, cairan serebrosinal serta dapat menghambat bakteri pathogen gram negatif dan positif. Seftriakson memiliki waktu paruh selama 7-8 jam, dapat larut dalam air serta relatif stabil terhadap peruhanan $\mathrm{pH}$ dan suhu, diekskresikan 60-90\% melalui ginjal. Obat ini bekerja dengan cara menghambat sintesis dinding sel bakteri dengan cara menghambat transpeptidasi peptidoglikan dan mengaktifkan enzim autoloitik dalam dinding sel yang menyebabkan kematian bakteri. Efektifitas seftriakson terhadap bakteri gram negatif sebesar $82 \%-95 \%$ dan bakteri gram positif sebesar $67 \%-90 \%$.

Siprofloksasin merupakan antibiotik golongan kuinolon generasi kedua yang lebih efektif terhadap bakter gram negatif dibandingkan bakteri gram positif. Siprofloksasin bekerja dengan cara menghambat replikasi DNA bakteri (inti sel bakteri) dengan cara menempel molekunya pada DNA girase (topoismerase II dan topoisomerase IV). Mekanisme yang langsung menuju intisel inilah yang menyebabkan bakteri dengan cepat dapat dieliminasi [8]. Efektifitas siprofloksasin bakteri gram negatif sebesar 70\%-86\% dan terhadap bakteri gram positif sebesar 55\%-87. Berdasarkan efektifitasnya seftriakson memiliki sensitifitas yang lebih tinggi 
terhadap bakteri gram positif dan negative bila dibandingkan dengan siprofloksasin[9].

\section{Interaksi antara antibiotik dan analgesik}

Berdasarkan hasil penelitian yang telah dilakukan kombinasi analgesik dan antibiotik yang paling banyak digunakan adalah seftriakson dan parasetamol, sefiksim dan parasetamol. Setelah dianalisis menggunakan buku referensi dan jurnal-jurnal didapat kan hasil tidak terdapat interaksi antara antibiotik dan analgesik yang diberikan kepada pasien ISK.

\section{KESIMPULAN}

Berdasarkan penelitian yang telah dilakukan dapat disimpulkan bahwa karakteristik pasien yang terserang ISK terbesar merupakan perempuan $81 \%$, usia remaja dan lansia $21 \%$, pekerjaan ibu rumah tangga (IRT) 35\%, dan tanpa penggunaan kateter $86 \%$, pola penggunaan antibiotik yang paling banyak digunakan untuk pengobatan ISK adalah golongan sefalosporin $67 \%$, obat dari golongan sefalosporin yaitu seftriakson $30 \%$. Analgesik yang paling banyak digunakan adalah golongan non opioid 96\%, obat dari golongan non opioid yaitu parasetamol $71 \%$, dan tidak terdapat interaksi antara antibiotik dan analgesik.

\section{DAFTAR PUSTAKA}

[1]. Pratiwi, Hening dan Septimawanto Dwi P. 2015. Evaluasi Peresepan Antibiotik Pasien Infeksi Saluran Kemih Di Instalasi Rawat Inap Rumah Sakit Roemani Semarang. Alternatif Medicine. Universitas Wahid Hasyim. Semarang.

[2]. Febrianto, Aldy W., Alwiyah Mukaddas., dan Inggrid Faustine. 2013. Rasionalitas Penggunaan Antibiotik Pada Pasien Infeksi
Saluran Kemih (Isk) Di Instalasi Rawat Inap Rsud Undata Palu Tahun 2012 . Natural Science. Untad.

[3]. Gibson, Kim and Joseph Toscano. 2012. Urinary Tract Infection. American Journal of Clinical Medicine.

[4]. Manthu, Fahijratin N.K., Lily Ranti Goenawi, Widdhi Bodhi. 2015. Evaluasi Penggunaan Antibiotik pada Pasien Infeksi Saluran Kemih di Instalasi Rawat Inap RSUP. Prof. Dr. R. D. Kandou Manado Periode Juli 2013 - Juni 2014. Jurnal Ilmiah Farmasi. UNSRAT. Vol 4 (4).

[5]. Putri, Rizki Artika, Yunie Armiyati, Mamat Supriyono. 2012. Faktor- Faktor yang Berpengaruh Terhadap Infeksi Saluran Kemih pada Pasien Rawat Inap Usia 20 Tahun Ke Atas dengan Kateter Menetap di RSUD Tugurejo Semarang. Jurnal Ilmu Keperawatan

[6]. Akhter T, Baqai R, Aziz M. 2010. Antibacterial Effect Of NSAID On Clinical Isolates Of Urinary Tract Infection And Diabetic Foot Infection. Pak J Pharm Sci. 23(1)

[7]. Setiabudy, Rianto. 2012. Farmakologi dan Terapi Edisi 5. Departemen Farmakologi dan Teraupetik Fakultas Kedokteran UI. Penerbit FKUI. Jakarta.

[8]. Triono, Aviv Aviv., Akhmad Edy Purwoko. 2012. Efektifitas Antibiotik Golongan Sefalosporin dan Kuinolon Terhadap Infeksi Saluran Kemih. Mutiara Medika. Vol. 12(1)

[9]. Maharia, M.G. 2009. Perbandingan Potensi Siprofloksasin dan Seftriakson Terhadap Escherichia Coli di Yogyakarta. Universitas Gajah Mada. Yogyakarta. 